\title{
Reviews
}

\section{The Prickly Problems of Pornography}

\author{
Willard M. Gaylin, M.D.
}

Foolish Figleaves? By Richard H. Kuh. New York: The Macmillan

Company, 1967. Pp. viii-xi, 368. \$7.95.

Obscenity is any picture or phonograph record or any written matter calling attention to reproductive organs, bodily discharge, or bodily hair. . . . The difference between pornography and art is bodily hair.

Thus spake Senator Rosewater in Kurt Vonnegut's blazingly funny satire God Bless You Mr. Rosewater, ${ }^{1}$ and in so speaking offered the only note of certainty and conviction in what has become a quagmire of confusion and chaos.

At the time of its most recent joust with the problem in early 1966, the Supreme Court had been struggling in its attempts to define obscenity and pornography since 1952. In some twenty cases (with the exception of three decided on one day in 1957) the direction of these efforts had been clear and the intention obvious. The Court was progressively and consistently liberalizing its attitude. Every expectation was for the continuation of this trend, which had reached a point signaling for all practical purposes the end of obscenity as a legal concept and therefore the end of all restrictions.

In a New York Times review of March 2, 1966, Elliot FremontSmith prematurely assumed precisely this result:

The free publication of "Story of $O$ " in this country is an event of considerable importance-not because the book has more than limited artistic merit (it probably doesn't) or because it is in some way attractive (it isn't), but because it marks the end of any coherent restrictive application of the concept of pornography to books.2

But three weeks later, the Supreme Court once again directed its attention to this problem. Utilizing three separate cases $^{3}$ requiring

1. K. VoNNEgUt, GOD Bless You Mr. ROSEWATER $71-72$ (1965).

2. Fremont-Smith, The Uses of Pornography, N.Y. Times, Mfar. 2, 1965, at 39, col. 2.

3. Ginzburg v. United States, 383 U.S. 463 (1966); Mishlkin v. New York, 383 U.S. 502 
fourteen different opinions, with little clarity and less consistency, with internal contradiction and obvious exasperation, to the chagrin of their boosters and the delight of their detractors, weary and wary the Justices managed, God bless them, to do precisely the right thing. They called a halt.

The intellectual community was not merely surprised by the decision -it was outraged. Undaunted by the monstrous trick of fate which cast Ralph Ginzburg as St. Joan, they rallied round-with petitions, full-page ads, fund raisings, and the other accoutrements of twentieth century evangelism. What emerged was a campaign which featured too many authoritative statements from the wrong people, raising the wrong questions, and supplying the wrong answers.

Rather than attacking the concept of obscenity, they defended Ginzburg. They attempted to prove that "these" works were not pornographic, thereby implying that there must be some unnamed others that are. There was a measure of intellectual dishonesty in this implicit position because this particular group would be unlikely to label any piece of literature as obscene (in the sexual sense). They lacked the guts to say what they meant-that in an age of sexual enlightenment there is no longer a role for obscenity as a legal concept. Of course, right or wrong, this is a respectable stance to assume in a free society which demands for the perpetuation of that freedom a minimum of restraints on the dissemination of ideas. The abolitionists would even find that they had respectable legal support. Justice Black and Justice Douglas have for years questioned whether there is any concept-libel, privacy, or, indeed, obscenity - which can support restriction of free expression. Justice Black reiterated in his dissent in the Ginxburg case:

as I have said many times, I believe the Federal Government is without any power whatever under the Constitution to put any type of burden on speech and expression of ideas of any kind (as distinguished from conduct). ${ }^{4}$

There is a purity to this kind of thinking which permits one to approach obscenity with unruffled thoughts and untroubled sleep. It is, however, a minority opinion and we have lived in a society under laws which have not interpreted the First Amendment with such a broad sweep. Nevertheless the question to be raised is whether obscenity laws serve any useful purpose or have even any definable mean. 
ing. The answer is not as obvious as those of us raised in the liberal tradition might initially suppose. By calling a halt the Court has bought time for an overdue, new, and better-considered evaluation of the problems of obscenity.

Unfortunately, thus far the pause which the Court has ordered has been filled largely by the recriminations of those who have wanted to abolish obscenity as a legal concept and be done with it. But now comes Richard Kuh with some thoughts on the other side. In Foolish Figleaves, Kuh takes a partisan look at pornography from a prosecutor's point of view. And it's about time. Passion and eloquence have been the purview of the libertarian. It is the pursed lip we associate with the censor. The artist tests limits (or should); the censor draws them. In a freedom-adoring society any educated man would instinctively prefer to identify with the former-at least if he aspires to acceptance by the intellectual establishment. So, while in life it is the defense of freedom that requires courage, in letters it is quite the opposite. Mr. Kuh has the courage to take an unfashionable position and the intelligence to present it plausibly.

The book consists of three major sections. The first is a superbly readable guide through the labyrinth of legal opinions on obscenity and the confusions and contradictions therein. In the second Kuh treats us to a delightfully down-to-earth narrative of his adventures in pornography land. He was an Assistant District Attorney in New York City for some 12 years, during which time he was personally involved in a number of significant censorship cases. He did not emerge unscathed. A no-nonsense pragmatist, he was frustrated by the legal system with its endless delays and embittered by the opposition of the intellectual community. He obviously didn't like playing the heavy. One can hear his friends saying "Come off of it, Dick." (Certainly during the Lenny Bruce trial dinner parties must have been unmitigated hell.) As a result these chapters tend to have a "my turn at bat" quality, and in his defensiveness he occasionally comes off sounding a little self-righteous and a bit too proper.

In the third section, Mr. Kuh sets out an intriguing and radical set of legislative proposals to deal with pornography. He does this out of a sense of the hopelessness of bringing clarity and definition to the current concept of obscenity, and out of the conviction that an "anything goes" policy is undesirable because of "those hazards to society that obscenity appears to pose." He is sure that there are hazards, and consequently he has no doubt of the need for restrictions on the traffic in 
pornography. But these convictions are but weakly supported in the book he has written. Is obscenity, whatever that is, really dangerous? Mr. Kuh's intuitive answers, for all their sincerity, will not satisfy the intellectual community which is his chosen adversary. Yet perhaps there is more substance to them than will meet the casual intellectual eye.

What is obscenity anyway? Webster's Third New International Dictionary defines obscene as "disgusting to the senses, usually because of some filthy, grotesque, or unnatural quality, . . . grossly repugnant to the generally accepted notion of what is appropriate, shocking." If you go to the dictionary you are already in trouble. In its peculiar way the law tends to define obscenity in almost exactly the opposite way. The prevailing official legal definition of obscenity is to be found in the Supreme Court's decision in Roth v. United States..$^{\circ}$ Material is ob. scene, the Court said, if "to the average person applying contemporary community standards the dominant theme of the material taken as a whole appeals to prurient interest."' 6 Further, besides appealing to prurient interest, obscenity must be "utterly without redeeming social importance"t and it must go "substantially beyond the customary limits of candor in description or representation."8

Preeminently obscenity must be prurient; that is, it must be sexually exciting. It might seem, therefore, that if you could prove that material was obscene by the standard dictionary definitions-that is, disgusting and loathsome - then that material could not be obscene by the legal definition. And this is precisely what the lawyers in the Mishkin case offered as an essential defense. Mr. Justice Brennan, while denying the value or pertinence of the argument in that case, lent credence to the logic behind it. He stated:

[A]pplicant's sole contention regarding the nature of the material is that some of the books involved in this prosecution, those depicting various deviant sexual practices such as flagellation, fetishism, and lesbianism do not satisfy the prurient appeal requirement because they do not appeal to a prurient interest of the "average person" in sex, that "instead of stimulating the erotic, they disgust and sicken." We reject this argument as being founded on an unrealistic interpretation of the prurient appeal requirement.

Where the material is designed for and primarily disseminated to a clearly defined deviant sexual group, rather than the public at

5. 354 U.S. 476 (1957).

6. Id. at 489 .

7. Id. at 484 .

8. Id. at 487 . 
large, the prurient appeal requirement of the Roth test is satisfied if the dominant theme of the material taken as a whole appeals to the prurient interest in sex of the members of that group.

What difference does it make if the law and the dictionary disagree? Law makes its own definitions and is bound only by its own definitions. If an amateur like myself gets confused because I assume that the law defines the word according to its basic dictionary meaning and usage, a professional lawyer must surely consider this naive. But evidently the confusion is not confined to the amateur because, appallingly, the Justices of the Supreme Court themselves seem to vacillate between the legal and the dictionary definitions, and while Justice Brennan is implying that if indeed the material were disgusting to all groups it would therefore not be prurient and therefore could not be obscene (certainly a logical position in terms of legal precedent), Mr. Justice Harlan seems to have gotten lost. In his Fanny Hill dissent he states that federal suppression of obscene matter should be constitutionally limited to publications often described as "hardcore pornography." And he says, "I would characterize as 'hardcore' that prurient material that is patently offensive or whose indecency is self-demonstrating."10

Mr. Justice Clark, it would seem, is four-square in the obscenity-isdisgusting camp. In one of those tragi-comic ways in which nature imitates art, he seems to share Senator Rosewater's distaste for pubic hair. In his dissent in Fanny Hill he says:

In each of the sexual scenes the exposed bodies of the participants are described in minute and individual detail. The pubic hair is often used for a background to the most vivid and precise descriptions of response, condition, size, shape, and color of sexual organs before, during, and after orgasms. ${ }^{11}$

If the Justices insist on considering offensive and disgusting as antithetical to prurient, they ought at least to decide which characterizes obscenity. I think their difficulty lies in the somewhat priggish assumption that something which is "disgusting" cannot be "exciting." It is here that the psychiatrist would consider the jurist naive.

Whichever way you define obscenity, how will you know? To whom must it be either disgusting or exciting and how can that be determined? In Jacobellis $v$. Ohio, ${ }^{12}$ Justice Brennan personally assumes

12. 378 U.S. 184 (1964). 
the responsibility for deciding what is obscene on behalf of his brethren, stating specifically that the issue "must ultimately be decided by this Court."13 Yet Justice Stewart in his Ginzburg dissent says: "But if the First Amendment means anything, it means that a man cannot be sent to prison merely for distributing publications which offend a judge's esthetic sensibilities, mine or any other's."14 And Justice Black in his Mishkin dissent, with understandable weariness and delightful candor, seems to be saying that no one should judge what people may read, and if anyone does, it shouldn't be me:

I wish once more to express my objections to saddling this Court with the irksome and inevitably unpopular and unwholesome task of finally deciding by a case-by-case, sight-by-sight personal judgment by the members of this Court what pornography (whatever that means) is too hardcore for people to see or read. If censorship of views about sex or any other subject is constitutional then I am reluctantly compelled to say that I believe the tedious, time-consuming and unwelcome responsibility for finally decicling what particular discussions or opinions must be suppressed in this country, should, for the good of this Court and of the nation, be vested in some government institution or institutions other than this Court. ${ }^{15}$

If instead of the decidedly above-average Supreme Court Justices, you take the reactions of "the average man" so popular in the law you will run into other difficulties. In United States v. Klaw Judge Moore observes:

Most of the witnesses testified that they found the material disgusting or revolting, but that lascivious and lecherous thoughts had not been aroused in them. ...

If the witnesses presented in this case provide any sampling these pamphlets and pictures stimulated no one's prurient interest.18

From this observation he moves to conclude:

Too easily the jury could aid suppression simply on the basis of speculations and suspicions about the prurient appeal of the material to some unknown, undefined person whose psyche is not known. With the First Amendment in the background this cannot be abided. ${ }^{17}$

13. Id. at 188 .

14. 383 U.S. at 498.

15. 383 U.S. at 516-17.

16. United States v. Klaw, 350 F.2d 155, 166.67 (2d Cir. 1965).

17. 350 F.2d at 167 . 
He goes on then to suggest that one solution might be to find expert witnesses properly qualified to inform the jury about what does or does not appeal to the prurient interest of the average man. ${ }^{18}$ I presume he means psychiatrists.

As a psychiatrist my first advice to Judge Moore would be about those witnesses of his. Don't you believe a word they tell you, Judge. We psychiatrists have long since recognized that the answers individuals give to questions about their personal, emotionally-charged feelings rarely bear any relevance to their true feelings. Ask-them-noquestions-they'll-tell-you-no-lies is lesson number one in psychoanalytic technique. Fortunately, there are other methods available to the trained psychoanalyst for determining an individual's feelings and responses.

If the psychoanalyst is about to be dragged into this pit of pornography there is a certain poetic justice about it, because to an extent greater perhaps than the judges recognize he has been responsible for the confusion that exists in this field. Law is in great part dependent on precedent and respects the small change. It is more comfortable with evolutionary processes than revolutionary ones. But we are living in a time of revolution in the psychological view of man. Not just in obscenity, but in many areas perhaps more important, psychoanalysis has upset the balance, the continuity, even the logic of the law. Purpose, intention, motive, responsibility, insanity, were concepts that were readily and easily defined when a jurist and a physician were partners in ignorance. Modern psychology has left the purely descriptive days of its youth and now understands behavior in much more dynamic and complex terms. As has been suggested previously, it is not necessary for legal definitions to conform to biological or psychological understanding. But it is part of the nobility of law that it has sought not just workable definitions but accurate and "true" definitions.

In search of this truth the law has turned to the "expert" both as witness and as citable authority. Psychoanalytic psychology in particular has modified traditional legal concepts and seductively influenced the progressive jurist. In the 1920's and 1930's psychoanalysis presumed to have all the answers. They seemed simple and directly applicable. By the 1950's and 1960's it was evident that the answers were more elusive-but by now the jurists were conditioned to thinking of behavior psychoanalytically, for they were willy-nilly, as are we all,

18. Id. 
products of an analytic age. While the psychoanalytic perspective has clarified, it has also confounded, for contradiction is inevitable between a system which is deterministic (psychoanalysis) and one which assumes free will (the law).

The law of obscenity clearly demonstrates some of these problems. In the Victorian days it may have been simple to equate the obscene with the prurient. Those hypocritical years pretended to suffer sexuality: it was a necessary but distasteful biological function, like defe* cation one presumes. But Freud dared to announce sexuality, not merely as a pleasure, but as the pleasure. What is more, Freud told us, we all play the game: women as well as men, children as well as adults, upper and lower classes. And if that weren't enough sexuality now has the medical imprimatur: it is what the Doctor orders. Sex is healthy, ergo good. It is the denial of sexuality that is sick, ergo evil.

If we are sure of all this, what is wrong with appealing to prurient interest? Isn't the appeal of all major art sensual? Appeals to the other senses are not considered vulgar. Yet our puritan tradition at one time interdicted those appeals as well, and the delights of the palate, ear, and eye were held obscene in their day. Titillation of our sexual appetite should be no more illegitimate, we are told, than the titillation of any other appetite-particularly in an age that pampers the individual and revels in pleasure.

So much for the prurient definition. But the law would not necessarily be any happier with what the psychoanalyst has to say about the "disgusting" and "perverse" concept of pornography. To the psychoanalyst "normal" sexuality is not the antithesis of perverse sexuality, but the integration and synthesis of it. Perverse sexuality is a part of normal sexuality. Indeed if such perversions as sado-masochism, exhibitionism, voyeurism, homosexuality, and the like, appealed only to the individual members of "deviant cults" the problem would be a small one. If all the witnesses in the courtroom and all the jutges deliberating these problems have found this literature only repellent and disgusting, we have been victims of a shocking statistical fluke. The witnesses and judges represent a peculiar sampling of our population. Pornographers write for large audiences, not small, and when in their wisdom they choose to emphasize the perverse it is because of the ubiquity, not the exclusivity, of its appeal.

Despite the fact that the experts have destroyed the foundations of the concept of obscenity, the jurists have held back. They had, perhaps, an intuitive sense that biological truth is not necessarily sociological 
truth and that the responsibilities of psychoanalysis and the law are quite different.

Certainly the Black-Douglas absolutism about free expression is the easiest position to defend with constancy and logic. Yet even staunch supporters of free expression seem reluctant to espouse complete abandonment of controls. Justice Stewart, after a firm enunciation of the rights guaranteed under the First Amendment, ends by holding out for some censorship privileges:

Because such is the mandate of our Constitution there is room for only the most restricted view of this Court's decision in Roth v. United States. ...

There does exist a distinct, easily identifiable class of material in which all of these elements coalesce. It is that and that alone which I think Government may constitutionally suppress, whether by criminal or civil sanctions. I have referred to such material before as hardcore pornography. ${ }^{10}$

The vast majority of confiscated material over the years has fallen into this category. (Unfortunately the cases considered by the Court in 1966 were not typically "hard-core.") It is infuriatingly easy to identify and difficult to define this material. Yet if we are to retain even a limited concept of criminal obscenity, due process would seem to demand some substantial definition.

The very factors that make this pornography so patent point us toward a possible standard of definition. This hard-core stuff is designed to be pornographic. The majority of such pornographic publications are written for pornographic purposes, that is, they are written specifically to make money in the pornographic market. They are intended to be pornographic. That is their sole reason for existence. That is their purpose.

When Scotland Yard confiscated twenty-one pictures by Jim Dine, the American pop artist was quoted as saying,

When a person can make a painting with good intentions and the police can come along and say it's dirty, I think that's a pretty sad state of affairs.

Mr. Dine says his intentions were good, and in his innocence he defines the nub of the matter.

Putting the question this way, however, only takes us out of one

19. 383 U.S. at $498-99$ (dissenting opinion). 
legal quandary and into another. Whatever problem we have in defin. ing obscenity is small potatoes compared with the legal agony over intention. The law has never succeeded in finding effective definitions of purpose, intention, and motive. Modern psychology, by introducing the concepts of unconscious intention, has only made the old definitions less acceptable without offering new ones. How could it? In a psychoanalytic frame of reference all behavior is intentional. The psychology of intent, then, is legally useless. Rather than determining intention the law can define indicators of behavior (arbitrary or not) which will represent a legal definition of intention (psychologically true or not) which both serves the purpose of the law and is measurable and recognizable.

Justice Brennan's decision in the Ginzburg case was a step in that direction. This one decision, most ridiculed and most attacked in intellectual circles, actually represents a new measure of sophistication in the law, and is, psychoanalytically speaking, the soundest statement of the day. It is a testament to Mr. Kuh's independence of thought that, counter-current, he fully credits the importance of this decision. Mr. Brennan said:

In the cases in which this Court has decided obscenity questions since Roth, it has regarded the materials as sufficient in themselves for the determination of the question. In the present case, however, the prosecution charged the offense in the context of the circumstances of production, sale, and publicity and assumed that, standing alone, the publications themselves might not be obscene. We agree that the question of obscenity may include consideration of the setting in which the publications were presented as an aid to determining the question of obscenity, and assume without deciding that the prosecution could not have succeeded otherwise. ${ }^{20}$

This was a further extension of a principal suggested in Roth that

the nature of the material is, of course, revelant as an attribute of the defendant's conduct, but the materials are thus placed in context from which they draw color and character. A wholly different result might be reached in a different setting. ${ }^{21}$

This simple statement, which has sparked such outrage, would be dismissed as a cliché if made to a group of psychologists, psychiatrists, or psychoanalysts. To them it goes without saying that no psychological

20. 383 U.S. at $465-66$.

21. 354 U.S. at 495 (concurring opinion). 
phenomenon has meaning outside of the motivational context in which it appears. The psychoanalyst would go even further. He would not merely say that the "nature of the material is of course relevant." He would say that you do not even know the nature of the material until you see the context in which it is presented-that it is indeed often the context which defines the nature.

Justice Douglas was evidently particularly offended by the Brennan formulation. He protested:

The sexy advertisement neither adds to nor detracts from the quality of the merchandise being offered for sale. And I do not see how it adds to or detracts one whit from the legality of the book being distributed. A book should stand on its orm, irrespective of the reasons why it was written or the wiles used in selling it. I cannot imagine any promotional effort that would make Chapter 7 and 8 of the Song of Solomon any the less or more worthy of First Amendment protection than does its unostentatious inclusion in the average edition of the Bible. ${ }^{22}$

But quite the contrary is true. Almost any work of art of a sexual nature can be given obscene overtones by the context in which it is presented. For that matter, nonsexual things can be presented as sexual. There is an old parlor game, which the Justice has evidently been spared, that involves passing out nursery rhymes and asking the participants to read them in a lascivious and lewd manner without changing a word. The talented can manage to make Mistress Mary sound like Fanny Hill's roommate.

My first interest in the whole problem of defining obscenity was aroused by a chance occurrence. Commuting to my office one morning, numbly fumbling my way toward my train, I noticed an addition to the colorful advertising posters that line the station platform. To one elegant large modern poster on which the sole original text had been "NEWSWEEK SEPARATES FACT FROM OPINION," some impudent graffitier (offended no doubt by the waste of space) had appended - "Eddy Sucks" and "Chirdie Eats A Big ONE." I was startled, not by the news, but by my reaction to it. I was offended-and as a psychoanalyst I had long since given up hope of being offended by anything anymore. The second interesting fact was that I seemed to be the only one who had noticed. In an attempt at light-hearted humor I turned to a cluster of friends and said, "He neglected to tell us whether that is fact or opinion." 'That couldn't have been as unfunny as the response 
would have indicated, and I recognized an embarrassment in what would pass as a rather sophisticated group of people.

What is obscene in these statements? There isn't a vulgar word in the usual sense, although I will admit that "suck" seems to give most people trouble regardless of how it's used. I thought about it for awhile. Was it the implied homosexuality? (And that isn't the necessary implication.) Unlikely. If it had stated that Eddy fucks or even that Edcly copulates the effect would have been the same.

What was obscene was the naked intention of the author. The pur. pose of the scribbling was to be obscene, to shock, and this purpose was announced by the place and form of the communication-by the motivational context in which it appeared. It was the medium, not the message. It is this, by the way, which is shocking to most people about the exhibitionist. An adult woman (or man for that matter) who has had ample opportunity to see and examine a male genital will none the less be shocked by the exhibitionist who exposes himself in a public place. It is the blatant and willful intrusion of this sexual intention into the privacy of our mood that is capable of making it obscene. We know that the sole purpose of the behavior is to shock us. And we know the intention, not from a psychoanalysis of the individual, but from the way in which the behavior is presented to us. Justice Douglas, failing to see the significance of context over content, should ask himself what is indecent in indecent exposure-that which is exposed, or the manner of exposure together with the intended audience.

In the September 1965 issue of Encounter, George Steiner wrote:

Sexual relations are or should be one of the citadels of privacy. . . . The new pornographers subvert this last vital privacy. They do our imagining for us. They take away the words that were of the night and shout them over the rooftops making them hollow. The image of our love-making, the stammering we resort to in intimacy, come pre-packaged. ${ }^{3}$

But Justice Stewart reminded us in his Ginzburg dissent that if the First Amendment means anything, it means that a man cannot be sent to prison merely for distributing publications which offend a judge's esthetic sensibilities (or for that matter anybody else's).

Censorship reflects a society's lack of confidence in itself. It is a hallmark of an authoritarian regime. Long ago those who wrote our First Amendment charted a different course. They believed a 
society could be strong only when it is truly free. In the realm of expression they put their faith, for better or for worse, in the enlightened choice of the people, free from the interference of a policeman's intrusive thumb or a judge's heavy hand. So it is that the Constitution protects coarse expression as well as refined, and vulgarity no less than elegance. ${ }^{24}$

It is evidently only in the realm of expression that we put our faith in the enlightened choice of the people. We restrict harmful drugs. We do not merely require that they be identified as harmful and leave to the individual the option of literally choosing his orm poison. There has always been a sharp legal distinction drawn between things and thoughts, between verbal behavior and motor behavior. Recall Justice Black's statement that the Constitution forbids any restriction on speech or expressions of ideas of any kind "as distinguished from conduct." This position obviously does not reflect any absolute elevation of individual freedom over the demands of social living (otherwise why exempt conduct?). The assumption is that an individual must be allowed the greatest liberty which is consistent with the rights of other individuals to be protected in their persons and interests. Implicit is the further assumption that conduct can harm others and thoughts cannot. Two hundred years ago it may have seemed true that "sticks and stones could break your bones but words could never hurt you." But modern psychiatry is built on Freud's recognition that words can hurt you.

Certainly one of the crucial considerations in the whole problem of obscenity is the question of whether literature or art can corrupt or harm. Unfortunately, for all the discussion about obscenity no one seems to be pressing for a solution to this problem. The reason is partly that the intellectual community which is concerned about matters such as this assumes the answer. We are assured daily in the newspapers and magazines that no one has ever been harmed by anything he has read. This reassurance is offered by such experts on psychological development and human behavior as art historians, English professors, novelists, literary critics, movie reviewers, and lawyers for the Civil Liberties Union.

In an informal poll among friends I asked if they would have any hesitation in leaving about, or making available to their children, such books as Fanny Hill, Tropic of Cancer, Last Exit to Brooklyn, etc. (I would rather have been able to cite the more frankly hard-core books-

24. 383 U.S. at 498 . 
but most of us have limited knowledge of this literature.) The majority admitted they would, but rather than intellectually defending their behavior, assumed it was a vestigial bias from a neurotic past. When asked if they felt any damage would result from exposing children to frank pornography, there was near unanimity that such exposure could not be harmful. Books do not corrupt, I was assured, by every category of professional acquaintance except one-the psychiatrist. Ironically, this group, and particularly the child psychiatrists, were not so sure. Of the half-dozen or so child analysts questioned, all agreed that while the problem was poorly researched and poorly understood, the potential for corruption would certainly seem to be there. It seems psychoanalysts today are the last of the blue-noses.

Surely we must have a solid answer to this question of harmfulness before we can decide intelligently whether and on what basis we should preserve a legal concept of obscenity. Yet when it is discussed at all in legal decisions (as Justice Clark inadequately attempted to do in Fanny Hill $),{ }^{25}$ the question is typically presented in the naive, simplistic terms of whether someone will read a book which will incite him to sexual violence or sexual acting out. This is not the issue, despite FBI Chief J. Edgar Hoover's well-known views to the contrary. Mr. Hoover has been reported as saying that "filthy literature is the great moral wrecker. It is creating criminals faster than jails can be built." ${ }^{20}$ We also have it on his authority that "the increase in the number of sex crimes is due to precisely sex literature madly presented in certain magazines." 27 But his medical judgments need not concern us here. They are no more reliable than any statement he might give us on the cause of cancer. The sexual criminal's problem is not merely his impulse, which he may share with "normal" people, but his impulsecontrol mechanisms. Clinically it can be demonstrated that pornographic literature can offer release as well as stimulation. In either case it is a minimal stimulus compared with the weight of the individual's lifetime of experiences, with developed behavior patterns which are already automatized and often compulsively driven.

It is in the period of growth when these patterns of behavior are laid down, when environmental stimuli of all sorts must be integrated into a workable sense of self, when sensuality is being defined and fears

\footnotetext{
25. See 383 U.S. at 451-53.

26. As quoted by Brown \& Buchanan, We Learned What Pornography Really Is, IIBERTX, Mar.-Apr. 1966, at 9.
}

27. Id. 
elaborated, when pleasure confronts security and impulse encounters control-it is in this period, undramatically and with time, that legalized pornography may conceivably be damaging.

Every psychoanalyst observes that the neurotically damaging aspects of an individual's personality are a product of a multitude of determinants. There are a variety of forces and counter-forces of which any particular behavior is only a balance or end-point. I have been impressed both in the histories of patients, particularly those with sexual perversions, and in the treatment of those sexual perversions, with how often a slight influence or a chance occurrence can destroy or regenerate. A homosexual patient at a crucial point in his treatment will become involved with a first date that has been arranged by a friend. She is a woman of tact and understanding, perhaps even with a neurotic need of her own to serve a man, and she can, in a week or a month, assuage the fears of ages and consolidate the insights that the psychoanalytic process has taken years to develop. Another patient on his first date may encounter a destructive, hostile woman who can permanently impair the development of the treatment. Many patients present histories in which one senses how seemingly trivial events at a crucial stage of their development in pubescence tipped the balance towards health or disease by initiating a direction or a process. Ironically, in sexuality it is rarely the ultimate heightening or intensifying of the drive that results from a destructive environment, but the crippling and constricting of it.

Marketing techniques in literature have changed drastically. The paper-back revolution together with the liberalization of the pornography laws mean that it is no longer necessary to have $\$ 15$ or $\$ 20$ to spend, or to know the specific locations where pornography can be purchased, or to be sufficiently motile to get there, in order to have access to the hard-core merchandise. It can be purchased in the neighborhood drug store, candy store, or stationery store where one buys school supplies-and for the same amount of money. If we continue to liberalize our legal attitudes to the point of legalizing pornography we can fairly assume that the stuff will become progressively more available at lower cost, presumably with the full facilities of the advertising industry to alert us to the bargains.

Moreover, the attitude of society as reflected in the law has an influence not only on who will read pornography but also on the impact of the literature on those who do. It is not for me, a psychiatrist, to lecture judges and legal scholars on the role of the law, but they must 
certainly be aware of the fact that when you make something legal you are doing more than making it allowable or exempt from prosecution. In our society, legal means legitimate, and legitimate means more. It means sanctioned and, psychologically at least, sanctioned implies approved, supported, and even encouraged.

In the unofficial poll I alluded to earlier, one point was stressed by psychiatrists (and by almost all of them) that was made by no other group. They made a distinction between the reading of pornography, as unlikely to be per se harmful, and the permitting of the reading of pornography, which was conceived as potentially destructive. The child is protected in his reading of pornography by the knowledge that it is pornographic, i.e., disapproved. It is outside of parental standards and not a part of his identification processes. To openly permit implies parental approval and even suggests seductive encouragement. If this is so of parental approval, it is equally so of societal approval-another potent influence on the developing ego.

This point may be illustrated by reference to another of the law's perplexing problem areas, the phenomenon of addiction. The psychodynamic factors involved in addiction are similar whether the addiction is food, alcohol, or drugs. Yet the population of food-addicts (obese patients), alcoholics, and drug addicts is startlingly different. A special type of person becomes a narcotic addict because becoming a narcotic addict requires, among other things, violating the law. He must be the sort of person before addiction who is willing to break the law. The drug addict therefore commits more crime to feed his habit than the food addict, not just because crime is more necessary for his supplies, but because the kind of person who becomes a drug addict is someone who is more willing to commit or capable of committing a crime. If drug-taking were legal, then the typical drug addict would be more representative of a cross-section of the population. Certainly cigarettes are a form of addicting drug and yet cigarette addiction does not appeal more to the criminal population than to the rest. Indeed, one of the upsetting psychological phenomena that was not anticipated with the liberalization of the narcotics laws in England was an increase in addiction among younger, healthier individuals. We see the same thing happening today with marijuana. The chief argument against legalizing marijuana has been the contention that it leads to greater addiction. In the past this contention was statistically correct. The typical marijuana smoker several years ago was indeed likely to go on to heroin addiction. This is not necessarily true today. While marijuana has not 
been legalized it has become socially acceptable among large groups of younger people and accordingly no longer are only sociopathic types smoking marijuana. It has "social sanction" in some circles. To legalize it would be to give it complete social sanction and encourage wider use. Whether this is desirable or not is another question not pertinent here. The point is that legalizing it would enhance its chances of becoming a social institution. The law is an instrument in the establishment of social behavior-and in the judging of it. The law, more than most lawyers seem to realize, is an ethical determinant and a moral force.

Given this, we must find a way of determining to what extent legalizing frank, hardcore pornography and the changes that legalization will initiate would affect the development of the individual. These questions have never adequately been studied because there has been no pressure to study them. The psychiatric authorities that are cited in many court decisions are for the most part authoritarian rather than authoritative. Their judgments are based on limited clinical experience and extensive personal bias.

Even where the psychiatrist has been surest of his data, complications have arisen in extrapolating from the effect on individuals to the effect on society as a whole. Psychoanalysis, particularly in its beginnings, was individual-oriented. It tended to focus on the individual as a universe -as an isolate. Its first great discoveries involved internal development and internal conflict. Ecology and ethology were neglected. It thought in terms of biological absolutes rather than sociological relatives. Its attitude toward sexuality, more than anything else, dramatizes the difficulties it got into. If neuroses are built on frustration of the sexual drive, then to stop neuroses, stop frustrating. It turned out to be not so easy. Man reaches biological maturity at age twelve or thirteen. He is at the height of his sexual drive in his teens and is capable of reproducing. With the increased complexity of civilized society there is an enforced delay of maturity, an artificially extended period of dependence. There is insufficient time before pubescence to educate the child to the increased demands of the adult societal role. Socially he is not ready to assume the responsibilities of parenthood. Biologically he is ready, more than willing, and able. Somehow a lid must be kept onat least during the adolescent phase. (It may be that the phenomenon of adolescence is an artifact of that unbiological suppression.) Much of sexual morality must have been unconsciously designed to keep the lid on. Psychiatrists today have a healthier respect for the positive value of repression as an ego-supporting maneuver. 
Now it may be that with the pill and future unknown birth control devices, artificial insemination and parthogenesis, we are on our way to a total separation of sexuality and fecundity. At such time a society could evolve which permitted free expression of sexuality at any age. While we are in transition, however, it would seem that it would not hurt to pause for further study as the Supreme Court has suggested in its recent decisions before totaly abandoning the ideas of obscenity and pornography. I am not sure, however, that I am ready to go along with Mr. Kuh's legislation.

His purpose is to avoid such "imprecise vocabulary" as obscene, patently offensive, hard-core, prurient, etc., by writing a series of laws which explicitly define everything that will be prohibited. In order to attain a sense of reasonableness he proposes a separate code for children; a separate code for public displays; and different criteria for public shows, pictured material and other images and written or recorded materials. The intention of the legislation is admirable. The timing is bad. We are in the midst of a sexual and moral revolution. Accepted community standards change from day to day. Things are moving fast, too fast. When he insists that the sale to minors (under 18) of any visual representation of nudity be prohibited, haven't we already passed him by? Particularly when precision requires such obsessive defining of nudity as to include among other things "the human female breast below a point immediately above the top of the nipple" (not even a little nipple?). Mr. Kuh, despite his charm and marvelous wit, already sounds a mite fusty-at least to these jaded analytic ears. Unless there is more evidence than here presented for urgent action, legislation can wait for further studies.

After all this it may still turn out that obscenity cannot corrupt. And even if it can, we may conclude that the family is better suited than the law to insulate the young and-failing that-to inform them that pornography is distinctly not within the sphere of adult society's approval. Moreover, even if obscenity can corrupt, we may decide that its corruption is a price worth paying. We may still opt for the BlackDouglas position that our society forbids any restrictions in the field of ideas, since the law serves society, not the individual. The assumption is that even in a democracy where respect for the individual is a basic tenet, what serves society will also be serving the individual. And it may well be that the framers of the First Amendment recognized that there is greater danger, not only to the society but to each individual within it, in any limitations on the dissemination of ideas than could 